\title{
Randoms Correction Indicator
}

National Cancer Institute

\section{Source}

National Cancer Institute. Randoms Correction Indicator. NCI Thesaurus. Code C116128.

An indication as to whether the device was set to correct for random noise generated by deflected positrons. 